\title{
Preparation of syngas from the semi-coke of Borodino coal for solid oxide fuel cells
}

\author{
Aleksey Dudinin ${ }^{1}$, Vladimir Tuponogovov ${ }^{1, *}$, Igor Karasev $^{1}$, and Anastasia Bagutdinova ${ }^{1}$ \\ ${ }^{1}$ Ural Federal University named after the first president of Russia B. N. Yeltsin, UralsENIN, 620002, \\ Yekaterinburg, Mira st, 19, Russia
}

\begin{abstract}
Syngas for the battery of solid oxide fuel cells is produced in a gas generator with a fluidized layer consisting of a mixture of electrocorundum and semi-coke of the Borodino coal at the temperature of $850{ }^{\circ} \mathrm{C}$, fluidizable by steam in a retort heated from the outside. The concentration of semi-coke is $627 \mathrm{~kg}$ per $1 \mathrm{~m}^{3}$ of mixture of electrocorundum and semi-coke. The heat of combustion of the obtained syngas is 13359 $\mathrm{kJ} / \mathrm{kg}$. Syngas is purified in a cyclone - dust collector and gas purification from $\mathrm{SO}_{2}$ and $\mathrm{H}_{2} \mathrm{O}$.
\end{abstract}

\section{Introduction}

Modern energy technologies based on the Renkin cycle do not allow one to obtain the process efficiency above $42-45 \%$ [1]. Progress in the efficient use of fuel can be achieved with the technology of direct conversion of the oxidation energy of fuels into electricity through fuel cells or their combination with gas turbine (GTU) or steam turbine installation (STI) [2 - 5]. Thus, their combination allows one to provide the reforming process necessary for transformation of methane into synthesis gas [6]. Solid oxide fuel cells (SOFC) are the most convenient elements, as they are used as fuel for synthesis gas [7 - 9], which is most frequently obtained by steam or air conversion of natural gas [10-15].

However, the reserves of organic fuels stored in the lithosphere of the Earth for $90 \%$ consist of coal [16 - 18]. Therefore, the methods of production of synthesis gas from coal [19] are developed, including in the fluidized layer [20], in which the perfect mixing of the solid phase provides a high coefficient of heat dissipation and uniform temperature distribution in the volume of the layer. The interconnection of coal gasification technology with SOFC allows one to produce electricity with efficiency of more than $60 \%$, to capture more than $90 \%$ of carbon dioxide and it is a promising solution for the development of coal power plants in the future [21]. Thus, emissions of pollutants will be significantly reduced in a cogeneration plant based on gas generator and fuel cell, providing much smaller emissions of $\mathrm{NO}, \mathrm{CO}, \mathrm{SO} 2$ and solid particles, which are typical for ordinary plants on SOFC [22]. In the majority of the system analyses conducted to the present date, only mass and energy balances are used, which do not solve such an important limitation of the SOFC operation as internal temperature [23].

*Corresponding author: v.g.tuponogov@urfu.ru 
To analyze the efficiency of the scheme elements, it is necessary to determine the temperature in the reactionary volume of the gas generator and its chemical efficiency.

\section{Gas generator experiments}

To determine the characteristics of the syngas, experiments were performed at a separate laboratory model for steam gasification of semi-coke in a fluidized layer.

For steam gasification the semi-coke of the Borodino brown coal with the following characteristics were used.

Table 1. Composition of the Borodino coal, \% by mass:

\begin{tabular}{|c|c|c|c|c|c|c|}
\hline $\mathrm{C}^{\mathrm{p}}$ & $\mathrm{H}^{\mathrm{p}}$ & $\mathrm{N}^{\mathrm{p}}$ & $\mathrm{O}^{\mathrm{p}}$ & $\mathrm{W}^{\mathrm{p}}$ & $\mathrm{A}^{\mathrm{p}}$ & $\mathrm{V}^{\text {daf }}$ \\
\hline 75.19 & 1.5 & 0.8 & 5.59 & 2.51 & 14.41 & 10.46 \\
\hline
\end{tabular}

The heat of combustion of semi-coke $Q_{H}^{*}=26362 \mathrm{~kJ} / \mathrm{kg}$.

The semi-coke was obtained at a pilot industrial installation of thermocontact coking at a temperature of $600^{\circ} \mathrm{C} \mathrm{c}$ at the CHP-1 in Yekaterinburg [26]. Fractional composition of semicoke used in experiments, $\%$ by weight is the following:

Fraction, um $/ \%$ by mass:

$0-135 / 0.76 ; \quad 315-400 / 1.25 ; \quad 400-800 / 2.03 / ; \quad 800-1000 / 2.8 ; \quad 1000-1200 / 15.5 ; \quad 1200-$ $1500 / 8.74 ; 1500-3000 / 11.35 ; 3000-3200 / 5 ; 3200-3400 / 8 ; 3400-3600 / 12 ; 3600-3800 / 17.57$; $3800-4000 / 15$.

During the experiments on the gas generator its retort was heated by electric heaters. The concentration of carbon in the fluidized layer was $627 \mathrm{~kg} / \mathrm{m}^{3}$ and the rest was an inert filler (electrocorundum). The concentration of combustible substances in the ash is $15 \%$.

Consumption of semi-coke in the gas generator is $4 \mathrm{~kg} / \mathrm{h}$, for the water steam overheated to $550{ }^{\circ} \mathrm{C}$ it is $6.4 \mathrm{~kg} / \mathrm{h}$. Molar ratio $\mathrm{H}_{2} \mathrm{O}: \mathrm{C}=1.4: 1$.Temperature in the layer was maintained at the level of $850{ }^{\circ} \mathrm{C}$ by a temperature regulator. The output of moist synthesis gas is 9.5 $\mathrm{kg} / \mathrm{h}$.

Table 2. Composition of the obtained moist syngas, $\%$ by volume

\begin{tabular}{|c|c|c|c|c|}
\hline $\mathrm{CO}_{2}$ & $\mathrm{CO}$ & $\mathrm{H}_{2}$ & $\mathrm{CH}_{4}$ & $\mathrm{H}_{2} \mathrm{O}$ \\
\hline 1.4 & 39.9 & 39.7 & 0.8 & 18.2 \\
\hline
\end{tabular}

Heat of combustion of moist synthesis gas is $q_{x 1}=13359 \mathrm{~kJ} / \mathrm{kg}$.

Data on composition of synthesis gas and heat of combustion obtained in the experiment are used for the further simulation of the unit.

\section{Simulation of processes in the gas generator}

In reactionary volume a stoichiometric reaction of carbon of semi-coke with water steam takes place at the molar relation of water and carbon $\mathrm{H}_{2} \mathrm{O}: \mathrm{C}=1.4: 1$, during which synthesis gas is obtained:

$$
\mathrm{C}+1.4 \mathrm{H}_{2} \mathrm{O}=0.0334 \mathrm{CO}_{2}+0.95 \mathrm{CO}+0.94 \mathrm{H}_{2}+0.0165 \mathrm{CH}_{4}+0.436 \mathrm{H}_{2} \mathrm{O}
$$

Endothermic effect of this reaction $q_{x 2}=2996 \mathrm{~kJ} /(\mathrm{kg}$ of syngas $)$. Mass specific isobaric true heat capacity of syngas at the layer temperature of $850^{\circ} \mathrm{C} \mathrm{C}_{\mathrm{SG}}=2.19 \mathrm{~kJ} /(\mathrm{K} \cdot \mathrm{kg}$ of syngas) [defined from the equation (1)]. 
Mass consumption of synthesis gas, required for production of $12 \mathrm{~kW}$ of electric power of ECG, $\mathrm{kg} / \mathrm{s}$

$$
B_{\mathrm{sg}}=\frac{Q_{\ni}}{q_{x 1} \eta}
$$

where $\mathrm{z}=0.345$ is the efficiency of the SOFC electrochemical generator battery taken in the first approximation on the basis of $[28,29]$.

For the production of $B_{\mathrm{sg}}=2.64 \times 10^{-3} \mathrm{~kg} / \mathrm{s}$ of syngas the following consumption of semi-coke is required, $\mathrm{kg} / \mathrm{s}$ :

of water steam, $\mathrm{kg} / \mathrm{s}$

$$
G_{\mathrm{sc}}=\frac{B_{\mathrm{sg}} \mu_{c}}{C^{p}\left(\mu_{c}+1.4 \mu_{\mathrm{H}_{2} O}\right)}
$$

$$
G_{\mathrm{H}_{2} \mathrm{O}}=\frac{B_{S G} \cdot 1.4 \cdot \mu_{\mathrm{H}_{2} \mathrm{O}}}{\mu_{\mathrm{C}}+1.4 \mu_{\mathrm{H}_{2} \mathrm{O}}}
$$

where $\mu_{\mathrm{c}}$ and $\mu_{\mathrm{H}_{2} \mathrm{O}}$ are molecular weights of carbon and water.

Chemical efficiency of the gas generator is:

$$
\eta_{\mathrm{x}}^{*}=\frac{B_{S G} \cdot q_{x 1}}{\left[G_{S C} \cdot Q_{\mathrm{H}}{ }^{*}+\left(q_{x 2}+C_{S G} \cdot t\right) \cdot B_{S G}\right]}
$$

\section{Description of the coal gas generator scheme for solid oxide fuel cells}

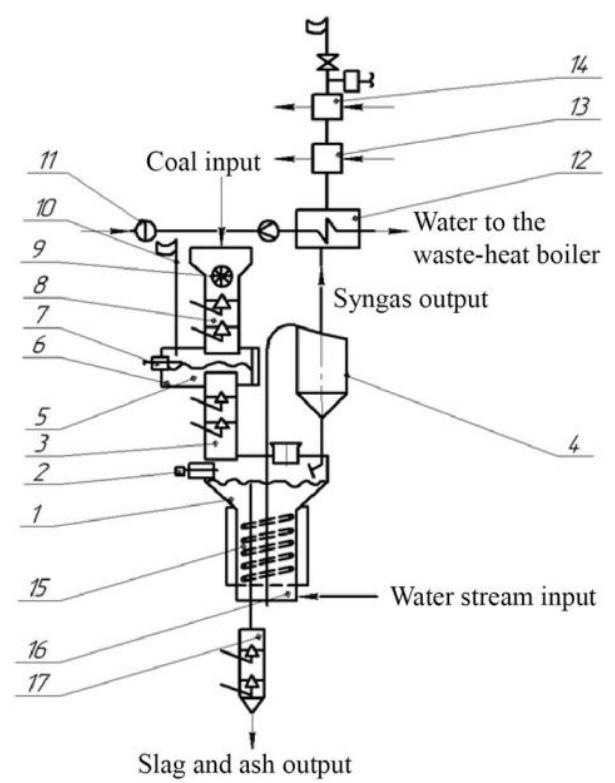

Fig. 1. Scheme of the gas generator with fluidized layer. $1-$ Gas generator with fluidized layer of semicoke; 2, 7 -igniter; 3 - sluice feeder for semi-coke; 4 - cyclone - ash catcher; 5 - furnace with fluidized layer of oxidized pyrolysis for removal of tar, acetic acid, turpentine, phenol from coal; 6 - air distribution grid; 8 - sluice coal feeder; 9 - coal crusher; 10 - candle for afterburning pyrolysis products; 11 - feeding pump; 12 - syngas cooler; 13 - a device for removal of sulfur dioxide from syngas; 14 a device for removal of hydrogen sulfide from syngas; 15 - tubular heat exchanger; 16 - steam distribution grid; 17 - airlock for ash and slag removal.

The Fig. 1 depicts the scheme of coal gas generator, in which the synthesis gas for the battery of the solid oxide fuel cell is produced in a gas generator with a fluidized layer consisting of a mixture of electrocorundum and semi-coke. 
Coal is milled by crusher 9 to the particle size of $3-5 \mathrm{~mm}$, then it is entered in the airlock feeder 8 , from which it is put into the furnace with a fluidized layer of weakly oxidative pyrolysis 5 to remove resin, acetic acid, turpentine and phenolics from coal. The formed semi-coke enters the gas generator through the sluice feeder 3 . The steam-distributing grate is fed by overheated in the boiler water steam. For ignition of the gas generator air supply is provided instead of water vapor. The thermal power spent on endothermic reaction, heating of products of this reaction and heat losses, is brought through the tubular heat exchanger 15, distributed in the fluidized layer, which is fed simultaneously by products from anode and air from the cathode channels of fuel cells.

The synthesis-gas obtained in the gas generator is discharged through the cyclone - dust collector, cooled, gas-cleaned from the remnants of sulfur dioxide and hydrogen sulfide by known dry technologies [26]. The purified synthesis-gas enters the waste-heat boiler for heating up to $750{ }^{\circ} \mathrm{C}$ and further into the anode channel of the SOFC.

\section{Thermal balance equation of the gas generator}

The amount of thermal power generated from the heated wall of the tubular heat exchanger 15 (see Fig.) $\alpha\left(t_{\text {wall }}-t\right) F$ and the capacities with dry semi-coke added to the volume of gas generator $q_{1} B_{\mathrm{sg}}$, moisture of semi-coke $q_{2}^{*} B_{\mathrm{sg}}$ and water steam $q_{3}^{*} B_{\mathrm{sg}}-\sum_{1}^{3} \quad q_{i} B_{\mathrm{sg}}$, is spent on endothermic reaction $q_{x 2} B_{\mathrm{sg}}$, heating of products of this reaction $c_{\mathrm{sg}} t B_{\mathrm{sg}}$, evaporation and overheating of steam from moisture of semi-coke $q_{4} B_{\mathrm{sg}}$, thermal loss in the surrounding area $q_{5}^{*}$, and chemical underburn $q_{3}^{* *}:\left(q_{x 2}+c_{s g} t+q_{4}\right) B_{s g}\left(1+q_{5}^{*}+q_{3}^{* *}\right)$.

$$
\alpha\left(t_{\mathrm{wall}}-t\right) F+\sum_{1}^{3} \quad q_{i} B_{\mathrm{sg}}=\left(q_{x 2}+c_{\mathrm{sg}} t+q_{4}\right) B_{\mathrm{sg}}\left(1+q_{5}^{*}+q_{3}^{* *}\right),
$$

Where the coefficient of heat transfer is $\alpha=0.740 \mathrm{kw} /\left(\mathrm{M}^{2} \mathrm{~K}\right)$ is calculated from [27], $q_{4}=W^{\mathrm{p}} h_{s o} m / 100$ is specific heat, spent on overheating of the steam from the moisture of the semi-coke.

The source data, including in the equation of thermal balance of the gas generator are:

The coefficient of heat output $\alpha=0.74 \mathrm{kw} / \mathrm{M}^{2} \mathrm{~K}$.

Surface area of the heat exchanger $F=0.12 \mathrm{~m}^{2}$.

Temperature of the wall of the heat exchanger $t_{\text {wall }}=1000^{\circ} \mathrm{C}$.

Temperature in the gas generator $t=850{ }^{\circ} \mathrm{C}$.

Mass consumption of syngas $B_{\mathrm{sg}}=2.64 \times 10^{-3} \mathrm{~kg} / \mathrm{s}$.

$q_{1},=17 \mathrm{~kJ} / \mathrm{kg} ; q_{2}^{*}=0.06 \mathrm{~kJ} / \mathrm{kg} ; q_{3}^{*}=253 \mathrm{~kJ} / \mathrm{kg} ; q_{3}^{* *}=0$ p.u.;

$q_{4}=34 \mathrm{~kJ} / \mathrm{kg} ; q_{5}^{*}=0.1$ p.u.; $q_{x 2}=2996 \mathrm{~kJ} / \mathrm{kg} ; C_{\mathrm{sg}},=2.19 \mathrm{~kJ} /(\mathrm{kg} \cdot \mathrm{K})$.

Enthalpy of overheated steam $h_{\text {so }}=3250 \mathrm{~kJ} / \mathrm{kg}$.

Mass of semi-coke to receive $1 \mathrm{~kg}$ of synthesis gas, $m=0.43, \mathrm{~kg} / \mathrm{kg}$.

Power consumed by the gas generator, KW:

$$
Q_{\mathrm{GG}}=\left[1.1\left(q_{x 2}+c_{\mathrm{sg}} t+q_{4}\right)-\sum_{1}^{3} q_{i}\right] B_{\mathrm{sg}}
$$

Power provided to the gas generator from the heater wall of the tubular heat exchanger 15 (see Fig.), KW:

$$
Q_{\mathrm{GG}}=\alpha\left(t_{\mathrm{wall}}-t\right) F
$$

The results of gas generator parameters calculations are presented in the table 3 .

Table 3. Results of calculations for the nominal operation of the electrochemical generator

\begin{tabular}{|c|c|c|c|}
\hline Parameter & $\begin{array}{c}\text { For- } \\
\text { mula }\end{array}$ & Expression for calculation & Value \\
\hline $\begin{array}{c}\text { Flow rate of syngas, } \\
B_{\mathrm{sg}}, \mathrm{kg} / \mathrm{s}\end{array}$ & $(1)$ & $\frac{12}{13359 \cdot 0.345}$ & $2.64 \cdot 10^{-3}$ \\
\hline
\end{tabular}




\begin{tabular}{|c|c|c|c|}
\hline $\begin{array}{c}\text { Flow rate of semi- } \\
\text { coke } G_{\mathrm{sc}}, \mathrm{kg} / \mathrm{s}\end{array}$ & $(2)$ & $\frac{2.64 \cdot 10^{-3} \cdot 12}{0.7519 \cdot(12+1.4 \cdot 18)}$ & $1.132 \cdot 10^{-3}$ \\
\hline $\begin{array}{c}\text { Flow rate of water } \\
\text { steam } G_{\mathrm{H}_{2} O}, \mathrm{~kg} / \mathrm{s}\end{array}$ & $(3)$ & $\frac{2.64 \cdot 10^{-3} \cdot 1.4 \cdot 18}{(12+1.4 \cdot 18)}$ & $1.78 \cdot 10^{-3}$ \\
\hline $\begin{array}{c}\text { Chemical efficiency of } \\
\text { gas generator } \eta_{\mathrm{x}}^{*}, \mathrm{o} / \mathrm{e} \\
(\%)\end{array}$ & $(4)$ & $\frac{2.64 \cdot 10^{-3} \cdot 13359}{1.132 \cdot 10^{-3} \cdot 26362+(2996+2.19 \cdot 850) \cdot 2.64 \cdot 10^{-3}}$ & $0.826(82.6 \%)$ \\
\hline $\begin{array}{c}\text { Power consumed by the } \\
\text { gas generator } Q_{\mathrm{GG}}, \mathrm{kW}\end{array}$ & $(5)$ & {$[1.1 \cdot(2996+2.19 \cdot 850+34)-270] \cdot 2.64 \cdot 10^{3}$} & 13.46 \\
\hline $\begin{array}{c}\text { Power provided to the } \\
\text { gas generator } Q_{\mathrm{GG}}, \mathrm{kW}\end{array}$ & $(6)$ & $0.74 \cdot(1000-850) \cdot 0.12$ & 13.46 \\
\hline
\end{tabular}

\section{Conclusions}

Experiments on the steam gasification of the semi-coke of the Borodino brown coal in the retort heated from the outside by electric energy showed that the composition of synthesis gas, \% by volume is the following: $\mathrm{CO}-39.9 ; \mathrm{H}_{2}-39.7 ; \mathrm{CO}_{2}-1.4 ; \mathrm{CH}_{4}-0.7 ; \mathrm{H}_{2} \mathrm{O}-18.3$. The temperature of combustion of synthesis gas is $13359 \mathrm{~kJ} / \mathrm{m}^{3}$.

The molar ratio of $\mathrm{H}_{2} \mathrm{O}: \mathrm{C}=1.4: 1$, the temperature of the fluidized layer is $850{ }^{\circ} \mathrm{C}$. The chemical efficiency of the gas generator is $82.6 \%$.

The conducted experiments provide the basis for the gas generator development for the production of syngas used in solid oxide fuel cells for production of $12 \mathrm{~kW}$ electric power. Heat is supplied in the reaction volume layer by a tubular heat exchanger, in which the oxidation of products coming out of the anode channel is performed by the air from the cathode channel. Power supplied to the volume of gas generator equals to $13.5 \mathrm{~kW}$. The oxidation products from the tubular heat exchanger are sent to the waste heat boiler.

\section{References}

1. D. Danvis, Energy (Stroyizdat, Moscow, 1985)

2. E.E. Shpilrayn, S.P. Malshenko, G.G. Kuleshov, Introduction to hydrogen energy (Energoatom-izdat, Moscow, 1984)

3. P. Lisbona, L.M. Romeo, International J. Hydrogen Energy 33(20), 5755-5764 (2008)

4. E.J.O. Promes, Applied Energy 155, 181-194 (2015)

5. A. Thallam Thattai, V. Oldenbroek, L. Schoenmakers, T. Woudstra, P. V. Aravind, Applied Thermal Engineering 114, 170-185 (2017)

6. A. Buonomano, F. Calise, M. D. d'Accadia, A. Palombo, M. Vicidomini, Applied Energy 156, 32-85 (2015)

7. S.B. Prakash, S.S. Kumar, S.T. Aruna, Renewable and sustainable energy reviews 36, 149-179 (2014)

8. A. Lanzini, D. Ferrero, M. Santarelli, CISM International Centre for Mechanical Sciences (Courses and Lectures) 574 (Springer, Cham, 2017)

9. Zh. Yingru, J. Power Sources 196(22), 9516-9527 (2011)

10. A.M. Dubinin, S.E. Shcelklein, V.G. Tuponogov, M.I. Erchov, Y.A. Kagramanov, International J. Hydrogen Energy 41(20), 8433-8437 (2016)

11. A.M. Dubinin, V.G. Tuponogov, I.S. Ikonnikov, Theoretical Foundations of Chemical Engineering 47(6), 697-701 (2013) 
12. A.B. Shigarov, V.A. Kirillov, Theoretical Foundations of Chemical Engineering 46(2), 97-107 (2012)

13. V.A. Kurganov, High Temperature 38(6), 926-937 (2000)

14. P Lakhete, V.M. Janardhanan, Chemical Engineering Science 110(3), 13-19 (2014)

15. A.M. Dubinin, G.R. Kagarmanov, O.A. Obozhin, Chemistry of solid fuels 3, 30-33 (2012)

16. S.E. Scheklein, Human. Energy. Nature, (Ed. USTU, Ekaterinburg, 2000)

17. M. Halien, I. Saarinen, M. Noponen, I.C. Vinke, Fuel Cells 10(3), 440-452 (2010)

18. J.P. Longwell, E.S. Rubin, J. Wilson, Progress in Energy and Combustion Science 21(4) 269-360 (1995)

19. D.S. Beznosova, D.G. Grigoruk, D.A. Lyalin, A.V. Turkin, Thermal Engineering 58(9), 774-778 (2011)

20. A.M. Dubinin, V.G. Tuponogov, D.V. Filippov, Thermal Engineering 56(5), 421-425 (2009)

21. M. Li, A.D. Rao, J. Brouwer, G.S. Samuelsen, J. Power Resources 195(17), 5707-5718 (2010)

22. V. Spallina, M.C. Romano, S. Campanari, G. Lozza, Energy Procedia 4, 1168-1175 (2011)

23. M. Li, A.D. Rao, J. Brouwer, G.S. Samuelsen, J. Power Resources 195(17), 5707-5718 (2010)

24. V.A. Sobyanin, Ros. chemical J. (J. Rus. Chemical Society named after D.I. Mendeleev) XLVII(6), 62-70 (2003)

25. R. Peters, International J. hydrogen energy 38(16), 6809-6820 (2013)

26. N.V. Zhavoronkov, Handbook of nitrogen. 2nd ed., reedit. (Himiya, Moscow, 1986)

27. A.P. Baskakov, V.V. Matsnev, I.V. Raspopov, Boilers and fluidized bed furnaces, (Energoatomizdat, Moscow, 1996) 